\title{
Long-term phosphorus fertilization effects on arbuscular mycorrhizal fungal diversity in Uruguayan grasses
}

\author{
Silvina García ${ }^{1}$, Fabiana Pezzani ${ }^{1}$, Andrea Rodríguez-Blanco ${ }^{2 *}$
}

${ }^{1}$ Ecología. Departamento de Sistemas Ambientales. Facultad de Agronomía.Universidad de la República. Av. E. Garzón 810, 12900 Montevideo, Uruguay. ${ }^{2}$ Microbiología. Departamento de Biología Vegetal. Facultad de Agronomía. Universidad de la República. Av. E. Garzón 810, 12900 Montevideo, Uruguay. *Corresponding autor:andrearb@fagro.edu.uy

\begin{abstract}
Arbuscular mycorrhizas (AM) are particularly relevant in grasslands due to the high colonization in grasses, main constituent of this ecosystem. Natural grassland (NG) is the dominant ecosystem of Uruguay and it supports one of the main economic activities of the country: livestock. Available phosphorus (P) contents in NG soils of Uruguay are low, so phosphate fertilization is frequent. The aim of this work was to study the effect of phosphorus fertilization on arbuscular mycorrhizal fungi (AMF) diversity of two native grasses of Uruguay: Paspalum dilatatum and Coelorhachis selloana. Diversity and abundance of AMF spores in the rhizosphere of grasses were studied using morphological techniques, while AMF diversity in roots was studied through TRFLP. The study was conducted in a long-term experiment of phosphorus fertilization in Uruguayan grasslands. The increase in available P did not affect the diversity of AMF in the roots or in the rhizosphere of the studied grasses. The richness of AMF biotypes in roots and spores abundance differed between host species, with higher values in $C$. selloana than in P. dilatatum. Differences in AMF diversity between seasons were observed, with greater number of biotypes in winter than in summer.
\end{abstract}

Keywords: Spores, T-RFLP, Paspalum dilatatum, Coelorhachis selloana, natural grassland 


\section{Introduction}

Arbuscular mycorrhizas (AM) derive from the interaction between fungi belonging to the phylum Glomeromycota and the roots of the majority of the terrestrial plants (Smith and Read, 2008). This symbiosis, very frequent in nature (Smith and Read, 2008; Brundrett, 2009), is of great relevance for the agricultural and natural systems due to its contribution to higher crop yield and for ecosystem sustainability (Castillo et al., 2016).

There is substantial evidence of the benefits plants get from mycorrhizas, among which the absorption of immobile nutrients such as P stand out (Smith and Read, 2008). However, further studies are necessary to understand how arbuscular mycorrhizal fungi (AMF) diversity can promote plant diversity and stable systems. Several studies show a positive correlation between the diversity of the AMF and the diversity of the associated plant community. This promotion of plant diversity by the mycorrhizal interactions could be explained as different species of AMF could provide plants with different services (Castillo et al., 2016). Furthermore, the spatial distribution of the AMF community could help to generate heterogeneous environments, which could contribute to maintain the plant diversity (Bever et al., 2001).

So far, within the phylum Glomeromycota, 270 species of fungi which form arbuscular mycorrhizas are known to date, distributed in 38 genera in 15 families and 5 orders (Glomerales, Diversisporales, Gigasporales, Archaeosporales, and Paraglomerales) (Castillo et al., 2016). This number of AMF species is capable of associating with approx. 200,000 plant species, which shows the low specificity of the mycorrhizal interaction (Brundrett, 2009). Most of the studied plant communities hold from 1 to 75 taxonomic units of AMF (Oehl et al., 2010).
The study of AMF communities is difficult considering that these fungi are obligate symbionts; therefore, they cannot be grown in vitro, away from their host plant (Smith and Read, 2008). Methodological strategies used to study AMF communities are conventional spore-based analysis and the DNA-based techniques. Conventional methodology identifies these fungi by morphological study of spores present in the rhizosphere of the plants which could be potentially colonized. On the other hand, DNA-based techniques allow the determination of AMF diversity both inside the roots of colonized plants and in the soil (Colombo et al., 2014). Molecular biology has revolutionized the knowledge of AMF biodiversity, making possible to characterize the AMF community of samples from different ecosystems. The community structure of AMF can be inferred from spore communities but it should be considered that the ecological and evolutionary forces that affect AM fungal species inside plant roots could differ from that affecting the spore communities in soil (Liu et al., 2012). Both methods have their strengths and weaknesses (Castillo et al., 2016) and the combined approach is still necessary to complete the study of AMF assemblage diversity. Within the DNA-based techniques, the fingerprints techniques are becoming more popular to study microbial communities. Among these techniques, the Terminal Restriction Fragment Length Polymorphism (T-RFLP) is one of the most used to study the AMF community (Mummey et al., 2005; Dickie and FitzJohn, 2007; Martínez-García et al., 2015).

It has been reported that biotic and abiotic factors influence AMF diversity (Castillo et al., 2016). Host plant identity as well as plant community composition and neighboring plant species are biotic factors that affect AMF community (Öpik et al., 2006). In addition, there are intrinsic fungal factors such as sporulation rate and 
dispersal capability that determine the abundance and distribution of AMF species in the community (Chaudhary et al., 2014). Climate variability (regarding the phenology of host plants) and edaphic factors are part of the abiotic factors that affect mycorrhizas. Seasonality effect on fungal communities has been studied showing contradictory results. Some studies did not find differences in the structure of the fungal communities among different sampling seasons (Davison et al., 2012). On the other hand, Tian et al. (2011) found that the number of spores in the rhizospheric soil showed variation with the season and the phenological stage of the host plant. Other studies reported only variations in the abundance of certain AMF taxons while global fungal community underwent no changes (Bever et al., 2001). Seasonality in AMF communities may be driven directly through abiotic factors such as temperature and rainfall (Zhang et al., 2016), or indirectly through changes in carbon availability from host plants (Dumbrell et al., 2011).

Numerous reports show that agronomic management practices have a substantial impact on AMF communities (Castillo et al., 2016), among which phosphorus fertilization has been the most studied (Kahiluoto et al., 2001; Liu et al., 2012; Sheng et al., 2013). Considering that in nutrient-poor and dry soils the arbuscular mycorrhizal benefits are greater (Pezzani et al., 2006), several studies found negative effects due to an increase in P availability on the diversity of AMF community. This effect was observed not only inside the roots (Liu et al., 2012) but also in plant rhizosphere, analyzing both spore density and number of AMF species (Kahiluoto et al., 2001; Sheng et al., 2013).

Natural grassland (NG) is the dominant ecosystem of Uruguay, accounting for $64 \%$ of the territory. It stands for the $78 \%$ perennial forage resources of Uruguay and it supports livestock, one of the main economic activities of the country. Grasses, the predominant family in grasslands, present a high colonization of AMF (Pezzani et al., 2006; García et al., 2016). In
Uruguay's NG soils, $\mathrm{N}$ is the main limiting nutrient for plant growth (Jaurena et al., 2015). In these soils, $\mathrm{P}$ contents are also particularly low and range from 3 to $5 \mathrm{mg} \mathrm{kg}^{-1}$ of soil (Garcia et al., 2016). In order to lift these nutritional restrictions, overseeding legumes and phosphorus fertilization are carried out. Although in the short term this practice has shown positive impacts over the nutritional forage quality, evidence shows a low persistence of introduced legumes species as well as undesirable changes in the floristic composition of the NG (Jaurena et al., 2015).

Jaurena et al. (2015) assessed the effects that overseeding legumes and phosphorus fertilization have on the floristic composition throughout a long-term experiment that includes two phosphorus fertilization treatments. Thirteen years after the experiment was installed, results showed differential responses of native grasses frequencies and an increase of exotic species such as Cynodon dactylon and Lolium multiflorum. Some of the native grasses disappeared from the community (e.g. Paspalum notatum, Stipa neesiana), others maintained their aerial cover (such as Paspalum dilatatum and Panicum hians), whereas others decreased without disappearing (e.g. Coelorhachis selloana). Furthermore, the legumes introduced when the experiment was established, presented a very low cover in fertilized plots (Jaurena et al., 2015). Fifteen years after continuous annually phosphorus fertilization the intensity of arbuscular mycorrhizal colonization in two grasses was studied: P. dilatatum and C. selloana. Both grasses were part of the plant community and showed different responses in their cover. Results revealed a reduction in AMF colonization in both grasses in fertilized plots (García et al., 2016).

A better understanding of the effects of land uses on AMF diversity will help to design more sustainable agronomic management practices (Castillo et al., 2016). For example, Alguacil et al., (2009) found 
that the application of organic wastes enhanced soil microbial activities and aggregation, and increased AM fungal diversity, particularly when a moderate dose of $13.0 \mathrm{~kg} \mathrm{~m}^{-2}$ was applied. The authors conclude that the application of organic amendments can help to mitigate the degradation of semiarid degraded lands, improving soil aggregation, microbial activities, and increasing AM fungal diversity even on a long-term basis.

The aim of this study was to determine the effects of $P$ fertilization on AMF community diversity in two native grasses of Uruguay. The specific objectives were: a) to study the effect of increasing $\mathrm{P}$ availability on mycorrhizal diversity in $P$. dilatatum and $C$. selloana roots, and b) to determine $\mathrm{P}$ fertilization effect on diversity and abundance of AMF spores in the rhizospheric soil of $P$. dilatatum and $C$. selloana. In order to achieve these objectives, we used a long-term phosphorus fertilization experiment in which AMF diversity in grass roots was assessed using the T-RFLP technique and spores diversity and abundance in the rhizosphere were approached using morphological studies. We hypothesized that an increase in P availability due to fertilization would have a negative effect on AMF community diversity of both grass species.

\section{Materials and Methods}

\subsection{Study site description}

The study was carried out in a field experiment established in 1996 at the Palo a Pique station of the National Agricultural Research Institute (INIA), which is located in Treinta y Tres, Uruguay $\left(33^{\circ} 14^{\prime} 58^{\prime \prime} \mathrm{S}\right.$, $\left.54^{\circ} 29^{\prime} 24^{\prime \prime} \mathrm{W}\right)$. The soils in the study area are a mixture of Abruptic Argiaquolls and Oxyaquic Vertic Argiudolls. The experiment consisted of three treatments: two levels of P fertilization (medium and high) and control plots of NG without fertilization. The experimental design consisted of three treatments with five replicates distributed in randomly chosen blocks, of 2 ha each. Three replicates were selected for the present study according to topographic and edaphic homogeneity, resulting in nine plots. This field has been under the same fertilization conditions for 16 years. At the time of sowing, in the medium level of P (MP), $45 \mathrm{~kg}$ $\mathrm{P}_{2} \mathrm{O}_{5}$ ha $^{-1}$ were added while in the high level of $\mathrm{P}(\mathrm{HP})$, $90 \mathrm{~kg} \mathrm{P}_{2} \mathrm{O}_{5}$ ha $^{-1}$ were added. Additionally, P fertilization was annually carried out in autumn: in the MP 30 $\mathrm{kg} \mathrm{P}_{2} \mathrm{O}_{5}$ ha $^{-1}$ year ${ }^{-1}$ and in the HP $60 \mathrm{~kg} \mathrm{P}_{2} \mathrm{O}_{5}$ ha $^{-1}$ year $^{-1}$ were added. When the experiment was installed, the legumes white clover (Trifolium repens) and birdsfoot trefoil (Lotus corniculatus) were overseeded together in all fertilized plots. These species were no longer present at the sampling date; therefore, the effect of the P fertilization was only assessed. In May 2011 P available content (P Bray I) was $16.3 \pm 2.7 \mathrm{mg} \mathrm{kg}^{-1}$ in HP plots, $8.36 \pm 6.2 \mathrm{mg} \mathrm{kg}^{-1}$ in MP plots and $2.7 \pm 0$ $\mathrm{mg} \mathrm{kg}^{-1}$ in control plots (García et al., 2016).

\subsection{Root sampling}

Grass species selected for this study presented the following features: a) have shown differential response in their relative aerial cover in response to $\mathrm{P}$ fertilization (following Jaurena et al., 2015); b) have presented high cover in plots and good forage quality and c) have been present in all the plots included in this study. Taking into account this selection criteria two species were selected: $C$. sellona, which reduced its cover in fertilized plots (decreasing species to $\mathrm{P}$ ) and $P$. dilatatum that its cover underwent no change because $\mathrm{P}$ increase (indifferent species to $\mathrm{P}$ ).

To homogenize grass cover height, cattle grazing was managed 15 days before the date of each sample in the nine studied plots. The remaining height of grass canopy at sampling was approximately $15 \mathrm{~cm}$.

Five different plants of $P$. dilatatum and five of $C$. sellona randomly selected were taken per plot, 
considering a minimum distance between plants no shorter than $5 \mathrm{~m}$. Samples were collected twice during 2012: one in February (summer-warm season) when the plants present the maximum growth rate (considering these are summer species) and the other in August (winter-cold season), when the plants present lower growth. The daily average temperature in February and August in 2012 was $27^{\circ} \mathrm{C}$ and $14.5^{\circ} \mathrm{C}$ respectively, and accumulated rainfall of $120 \mathrm{~mm}$ in February and $129 \mathrm{~mm}$ in August.

\subsection{DNA extraction from roots and Terminal Restric- tion Fragment Length Polymorphism (T-RFLP)}

Roots of five plants of each species were mixed thoroughly to obtain one representative sample per plot. Healthy white roots were separated from darker senescent roots, and adhering soil was washed off using deionized water. The roots were cut to $1 \mathrm{~cm}$ lengths, thoroughly mixed and macerated in liquid nitrogen until powder consistency. Total DNA was extracted from $100 \mathrm{mg}$ of roots following Gollotte et al. (2004) with modifications. Roots were mixed with $1000 \mu \mathrm{L}$ of 2X CTAB buffer and incubated for one hour at $65^{\circ} \mathrm{C}$, stirring it every $15 \mathrm{~min}$. Tubes were cooled at room temperature and were centrifuged at $12000 \mathrm{rpm}$ for 10 $\min$. The supernatant was removed and a volume of chloroform: isoamyl alcohol 24:1 was added, stirred for $5 \mathrm{~min}$ and centrifuged at $12000 \mathrm{rpm}$ for $5 \mathrm{~min}$. The aqueous phase was removed to a new tube where $2 / 3$ of volume of cold isopropanol was added. It was agitated by inverting it several times, and taken to a freezer for $2 \mathrm{~h}$. They were centrifuged for $10 \mathrm{~min}$ at $12000 \mathrm{rpm}$. The supernatant was discarded; the pellet was rinsed with $70 \%$ alcohol, centrifuged for $5 \mathrm{~min}$ at $12000 \mathrm{rpm}$ and then washed again with $70 \%$ alcohol. The supernatant was discarded and the pellet was dried overnight. The DNA was resuspended with $25 \mu \mathrm{L}$ of TE (10 mM Tris [pH 8.0] $1 \mathrm{mM}$ EDTA). The obtained product was visualized on a $1 \%$ agarose gel dyed with Good View (SBS, China). The electrophoresis was done at $90 \mathrm{~V}$ for $40 \mathrm{~min}$ using TBE $0.5 \mathrm{X}$ as buffer.

The community structure of root-colonizing AMF was assessed by T-RFLP amplifying a region of the 18S rDNA of Glomeromycota fungi. A nested PCR strategy was performed Primers LR1 (5'-GCA TAT CAA TAA GCG GAG GA-3') and FLR2 (5'-GTC GTT TAA AGC CAT TAC GTC-3'), whose are specific for fungal division (Trouvelot et al., 1999), were employed in the first amplification reaction. Primer FLR3 (5'-TTG AAA GGG AAA CGA TTG AAG T-3') and FLR4 (5'-TAC GTC AAC ATC CTT AAC GAA-3'), which were specific for Glomeromycota (Gollotte et al., 2004), were used in the second PCR reaction. The final concentrations of both PCR reactions were: buffer $1 \mathrm{X}, 2.5 \mathrm{mM}$ of $\mathrm{MgCl}_{2}, 0.5 \mu \mathrm{M}$ of each primer, $5 \mathrm{mg} \mathrm{mL}^{-1}$ of BSA, $1 \mathrm{U}$ of Taq polymerase (Fermentas, USA), $5 \mu \mathrm{L}$ of $1 / 10$ diluted DNA and water to complete $25 \mu \mathrm{L}$. PCR was performed in a thermal cycling (Biometra, Germany), programmed as follows: 5 min of denaturation at $94{ }^{\circ} \mathrm{C}$ for the first step; 35 cycles of 1 min of denaturation at $94{ }^{\circ} \mathrm{C}, 1$ min of annealing at $58{ }^{\circ} \mathrm{C}$, and $1 \mathrm{~min}$ of elongation at $72{ }^{\circ} \mathrm{C}$; and $10 \mathrm{~min}$ of final elongation at $72{ }^{\circ} \mathrm{C}$. Fluorescent fragments were generated via nested PCR amplification (as described above) using FAM-labeled FLR3 primer in the second reaction and PCR product of the first amplification diluted 1/10.

Products of these amplifications were resolved by gel electrophoresis in $1 \%$ agarose with TBE $0.5 \mathrm{X}$ buffer at $90 \mathrm{~V}$ for $40 \mathrm{~min}$, dyed with Good View (SBS, China) and observed in transilluminator. In order to decrease variations in the PCR process, samples were amplified in triplicate and the three PCR products were pooled and then purified with a Gene JET Gel Extraction kit (Thermo Scientific, USA), in darkness conditions. The obtained DNA was quantified in $1 \%$ agarose gel using the molecular weight marker Gene 
Ruler 100 pb DNA (Fermentas, USA). Approximately, $100 \mathrm{ng}$ of purified amplicons were digested with $5 \mathrm{U}$ of MboI (Fermentas, USA) at $37^{\circ} \mathrm{C}$ for $5 \mathrm{~h}$ followed by $15 \mathrm{~min}$ at $65^{\circ} \mathrm{C}$ to denature enzyme. Samples were analyzed by Macrogen Corp.S.A. (Korea) using an ABI3730X (Applied Biosystems) and GS500LIZ as a standard.

\subsection{Analysis of the T-RFLP data}

GeneScan 3.7 software (Applied Biosystems, USA) was used to analyze fragment sizes and peak fluorescence intensities. T-RFs between 30 and 360 bp were included in the analysis. The relative frequency of each peak in a given sample was calculated using the T-Rex program (Culman et al., 2009). Peaks that represented at least $1 \%$ of the total peak area for a given sample were included in our analysis; peaks below this threshold were assigned a value of $0 \%$. The richness $(\mathrm{S})$ of AMF in each sample was estimated based on a matrix considering presence (1) or absence ( 0 ) of each T-RF. The Shannon diversity index (H') and the Pielou evenness index ( $\mathrm{J}$ ') were estimated based on the relative abundance of each T-RF in the community using the software PAST 2.07 (Hammer et al., 2001).

\subsection{Rhizospheric soil sampling and greenhouse ex- periment}

In order to determine the abundance and diversity of the spores in the rhizosphere of the studied grasses, a greenhouse experiment was carried out. In autumn 2012 five plants of $P$. dilatatum and of $C$. selloana of each plot of the NG and HP treatments were collected with a block of soil of approximately $30 \mathrm{~cm}$ of diameter and $20 \mathrm{~cm}$ deep. To reduce the effect in the rhizosphere of those other plants which coexisted in the field, $P$. dilatatum and C. selloana plants were separated from neighbor plant species present in the blocks of soil.
The studied plants were then divided to create individuals with 3 tillers each. Fifteen individuals corresponding to the HP treatment and 15 to the NG treatment were separated to consider 5 individuals per plot. Each individual was planted in a polyethylene pot of $14 \mathrm{~cm}$ of diameter and $20 \mathrm{~cm}$ high containing $2.8 \mathrm{~kg}$ soil: sand (3:1 mixture of soil belonging to each plot and river sand). Plants were watered with $50 \mathrm{~mL}$ of previously decanted water (in order to volatilize the chlorine). The frequency of irrigation was adjusted based on water loss measurements (considering the difference between the weights of the pots watered with $50 \mathrm{~mL}$ and the weight in the following days until reaching the initial weight prior to the irrigation). Pots were rotated once a week to avoid possible effects related to their position in the greenhouse. After six months, the rhizospheric soil was separated to isolate the AMF spores.

\subsection{Abundance and diversity of spores}

The soil of the five pots corresponding to each plot of each treatment (NG and HP) and each species was mixed up to obtain composite samples. Spore abundance was quantified by extracting spores from a 100 g subsample of this resulted soil by wet sieving and density centrifugation proposed by Menge (Daniels and Skipper, 1982). Spores were also used to assess AM fungal diversity according to morphological characteristics. Spores were collected and mounted on glass microscope slides for classification and enumeration using a stereomicroscope (Nikon, Eclipse E100, Japan). Different morphotypes of spores were separated and classified by color, shape, subtending hypha features and some spores wall attributes according with Blaszkowski (2003). The spores were named with numbers in order of appearance. The number of morphotypes found in each sample represented the $\mathrm{S}$ of AMF spores; the number of spores of 
each morphotype represented the relative abundance and the total number of spores represented the total abundance of these AMF propagules.

Richness of spores morphotypes, H' and J' were calculated using the PAST 2.07 software (Hammer et al., 2001).

\subsection{Statistical analysis}

For the T-RFLP data, the analyzed factors were host plant, season of the year and treatment; and the response variables were S, H' and J'. The analyzed factors for spores data were host plant and treatment; the response variables were spore abundance, morphotype richness and the spore diversity indexes. T-RFs and spores morphotype $\mathrm{S}$ and spore abundance were analyzed using a Mixed Generalized Linear Model (MGLM), Poisson family. The diversity indexes H' and $\mathrm{J}$ ' for T-RFs and spores morphotype were analyzed using a Generalized Linear and Mixed Model. Differences between the compared averages were analyzed through the Least Significant Difference (LSD) test, with a significance $\mathrm{p}$-value $=0.05$, applying Bonferroni-adjusted, using the statistics program INFOSTAT (Di Rienzo et al., 2014).

A Bray-Curtis dissimilarity matrix among samples was calculated using the matrix of T-RFs relative abundance. Differences in community structure were analyzed with Non Metric Multidimensional Scaling (NMDS) using the software PAST 2.07 (Hammer et al., 2001). The same matrix was used to perform analysis of similarity (ANOSIM) to test significant differences in the AMF community composition associated to C. selloana and P. dilatatum.

\section{Results}

\subsection{Diversity of $A M F$ in the roots of $C$. selloana and P. dilatatum}

T-RFLP data showed that $P$ fertilization had no effect on AMF diversity present in the roots of the studied grasses. The H' and J' were not affected by the treatment (for H' $\mathrm{p}$ $=0.5299$; for $\mathrm{J}^{\prime} \mathrm{p}=0.3097$ ). The diversity indexes were not affected by the species (for H' $\mathrm{p}=0.5846$; for J' $\mathrm{p}$ $=0.3924$ ), by the season (for H' $\mathrm{p}=0.2045$; for J' $\mathrm{p}=$ 0.2274 ), or by their interactions. Shannon index varied from 1.8 and 2.7; both values correspond to $C$. selloana samples from HP treatment in summer and winter respectively. Pielou evenness index ranged between 0.76 and 0.87 and were registered in C. selloana roots in winter in NG and HP plots respectively.

After the normalization of the T-RFLP profiles, 68 different biotypes or T-RFs were identified, varying from a minimum of 6 and a maximum of 25 T-RFs per sample. Overall average of T-RFs for both samplings was $14.3 \pm 3.3$. T-RF richness was affected by host species $(p=0.0377)$ and season of the year $(p=0.0114)$ (Figure 1) but there were no significant differences in $\mathrm{T}-\mathrm{RF}$ richness between $\mathrm{P}$ fertilization conditions $(\mathrm{p}=$ 0.3971). C. selloana showed higher T-RF richness in its roots than P. dilatatum, while both species showed a significantly higher richness in cold season than in warm season (Figure 1). 


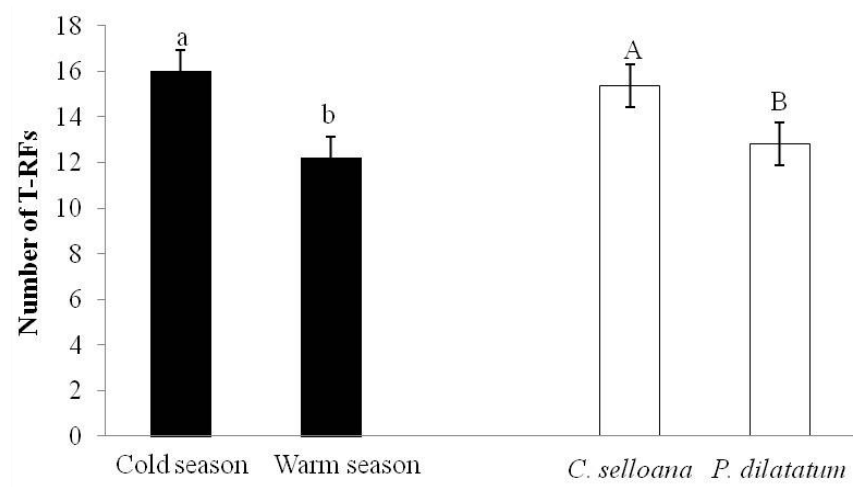

Figure 1. Arbuscular mycorrhiza fungal (AMF) richness (number of T-RFs) in roots of Paspalum dilatatum and Coelorhachis selloana in warm and cold season. Mean values of three $\mathrm{P}$ treatments $(\mathrm{n}=9)$ and standard error are shown. Means with different lowercase letters indicate significant differences between seasons. Means with different uppercase letters indicate significant differences between species (LSD test, $p=0.05$ )

NMDS analysis of T-RFLP data enabled us to graphically separate AMF communities under different $\mathrm{P}$ fertilization treatments (Figure 2). The global $\mathrm{R}$ statistics from ANOSIM for P treatments was 0.05 $(\mathrm{p}>0.05)$ indicating that there were not differences in AMF community by $\mathrm{P}$ fertilization. However, there was an appreciable season effect on the AMF community structure and NMDS analysis grouped the samples according to the season of the year (Figure 2). The $\mathrm{R}$ value for season comparison was 0.5612 with $\mathrm{p}<0.0001$, demonstrating that the difference between season was statistically significant.

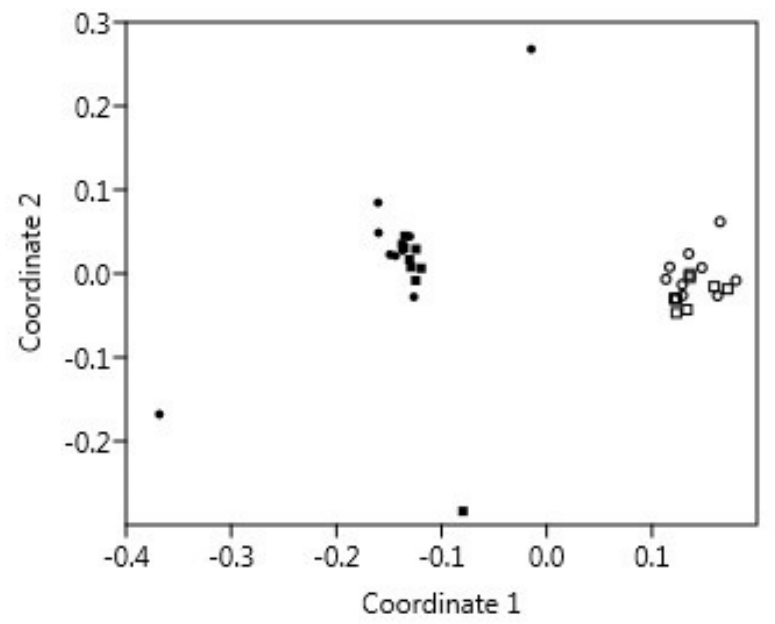

Figure 2. Multidimensional scaling (NMDS) plot of AMF community composition based on Bray-Curtis similarities of the T-RFLP data consisting of the relative abundance of the T-RFs. Circles: C. selloana; square: $P$. dilatatum; black: cold season, white: warm season, in natural grassland and fertilized plots. Stress: 0.17. 
Table 1 shows the most abundant AMF T-RFs in the roots of the studied grasses. A total of five T-RFs, with great abundance, were found to be common to all TRFLP profiles, among which the $185 \mathrm{pb}$ T-RF stands out and it was dominant in all the analyzed samples. On the other hand, only one T-RF was unique to $P$. dilatatum roots $(221 \mathrm{pb})$, while other two T-RFs were unique to C. selloana roots (211 and $109 \mathrm{pb}$ ). T-RFs corresponding to 230, 199 and $300 \mathrm{pb}$ were present only in the cold season. Finally, $97 \mathrm{pb}$ T-RF showed a high frequency but was only present in C. selloana roots in the cold season (Table 1). Specific T-RFs could not be associated to $\mathrm{P}$ treatment.

Table 1. Relative abundance of the main T-RFs (biotypes) in Paspalum dilatatum and Coelorhachis selloana roots at each sampling time (warm and cold season).

\begin{tabular}{ccccc}
\hline & \multicolumn{3}{c}{ Relative abundance (\%) ${ }^{(\mathrm{a})}$} \\
\cline { 2 - 5 } T-RF size $(\mathrm{pb})$ & \multicolumn{2}{c}{ P. dilatatum } & \multicolumn{2}{c}{ C. selloana } \\
\cline { 2 - 5 } 185 & 30.0 & 18.0 & 26.5 & 21.3 \\
151 & 13.0 & 7.8 & 13.0 & 8.7 \\
226 & 5.7 & 3.1 & 8.5 & 5.1 \\
105 & 6.1 & 7.2 & 4.5 & 2.3 \\
54 & 4.5 & 5.0 & 7.0 & 3.3 \\
221 & 2.7 & 5.4 & 0 & 0 \\
230 & 0 & 6.3 & 0 & 0.5 \\
199 & 0 & 1.2 & 0 & 1.8 \\
300 & 0 & 1.0 & 0 & 1.2 \\
211 & 0 & 0 & 3.5 & 1.2 \\
109 & 0 & 0 & 2.0 & 1.6 \\
97 & 0 & 0 & 0 & 8.6 \\
\hline
\end{tabular}

(a) Mean values for three $\mathrm{P}$ treatments $(\mathrm{n}=9)$

\subsection{Diversity and abundance of spores in C. selloana and $P$. dilatatum rhizosphere}

AMF spores diversity was not affected by $\mathrm{P}$ fertilization. Furthermore, morphotype richness as well as the diversity indexes were not affected by host species (for $\mathrm{S} \mathrm{p}=$ 0.6142; for H' $\mathrm{p}=0.5433$; for J' $\mathrm{p}=0.7338$ ), treatment (for $\mathrm{S} p=0.7121$; for $\mathrm{H}^{\prime} \mathrm{p}=0.5220$; for J' $\mathrm{p}=0.4552$ ), or the interaction between both factors (for $\mathrm{S} p=0.6142$; for H'p = 0.8143; for J' $\mathrm{p}=0.9033$ ), Nevertheless, spore abundance was significantly affected by host species $(\mathrm{p}=0.005)$ and species $\mathrm{x}$ treatment interaction $(\mathrm{p}=$ 0.0006). Coelorhachis selloana showed a significantly higher number of spores than $P$. dilatatum in its rhizosphere (Figure 3) and these differences between host plants were observed exclusively in HP plots. Furthermore, in C. selloana we observed a trend in the spore abundance that showed a greater number of spores in the rhizosphere of plants from HP treatments in comparison to the ones from NG plots. This trend was not observed in P. dilatatum rhizosphere (Figure 3). Spores abundance in $100 \mathrm{~g}$ of rhizospheric soil presented an average of $29 \pm 1$. 


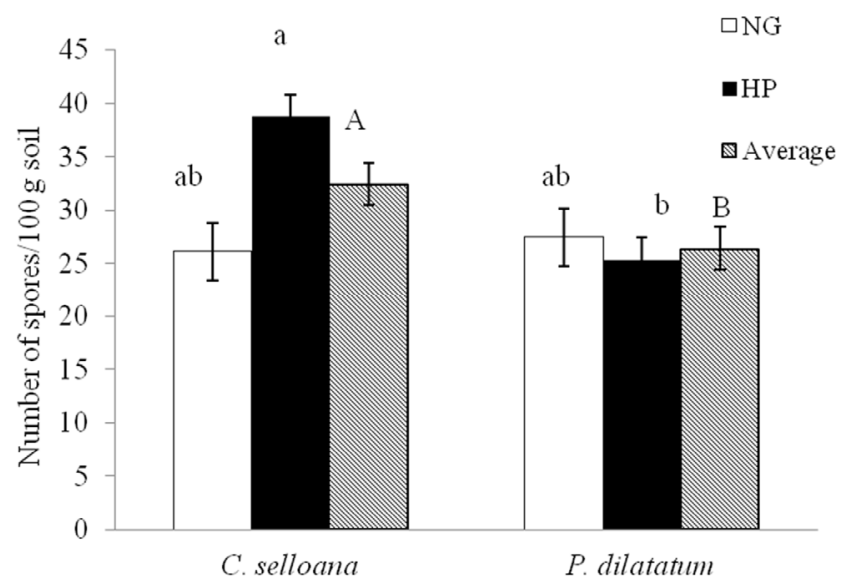

Figure 3. Spore abundance in Paspalum dilatatum and Coelorhachis selloana rhizospheric soils of natural grassland (NG) and fertilized plots with high levels of $\mathrm{P}(\mathrm{HP})$. Means $(\mathrm{n}=3)$ and standard error are shown. Different lowercase letters show differences between treatments. Different upper case letters show differences between species (LSD test, $\mathrm{p}=0.05$ ).

Analyzed rhizospheric soils showed a total of 15 different AMF spores morphotypes, with a minimum of 6 morphotypes and a maximum of 11 per sample. Among the most abundant morphotype the number 11 stands out, which was also present in all the analyzed treatments. The spores identified with this morphotype were big, translucent light brown coloring; they presented a single wall and were formed terminally in the subtending hypha, which showed an even thickness. Morphotype 8 corresponded to medium-sized spores, with single wall, reddish color, and in some cases the bulbous supporting hypha could even be observed, which presented a thickening in the base of the spore.. Another of the most abundant morphotypes present in all the studied samples was number 9 , corresponding to very small spores, reddish, forming groups from four to eight spores, which were formed terminally from straight subtending hyphas.

\section{Discussion}

In this study, the effect of overseeding legumes and long-term phosphorus fertilization on the diversity of AMF communities in roots and rhizospheric soil of two native grasses in Uruguay's grasslands was determined. Particularly, the effect of $\mathrm{P}$ fertilization was evaluated since the legumes introduced at the beginning of the experiment had disappeared from the community when the sampling was done. Contrary to our hypothesis, the obtained results showed that the increase in P soil available did not affect the diversity of AMF neither in roots nor in the rhizosphere of the studied grasses. This is a surprising result bearing in mind that the increase of $\mathrm{P}$ availability affected the floristic composition of the natural grassland (Jaurena et al., 2015). These changes could lead to alter the AMF communities, as most AMF show some level of host-preferences (Mummey 
et al., 2005; Öpik et al., 2006). On the other hand, previous studies report negative effects of increasing $\mathrm{P}$ availability on AMF diversity, independently of the amounts of available P in soil. Liu et al. (2012) observed a reduction in AMF species when available $\mathrm{P}$ changed from 2,8 to $42,2 \mathrm{mg} \mathrm{Kg}^{-1}$, while Sheng et al. (2013) observed the same result even with much lower change in available $\mathrm{P}$ ( 15 to $25 \mathrm{mg} \mathrm{Kg}^{-1}$ ).

In the long term experiment at Palo a Pique Station, after 16 years of $P$ fertilization, available $P$ contents in MP plots $\left(8,3 \mathrm{mg} \mathrm{Kg}^{-1}\right)$ were three times higher than in NG plots (2,7 mg Kg$\left.{ }^{-1}\right)$, while HP plots (16,3 $\left.\mathrm{mg} \mathrm{Kg}^{-1}\right)$ showed available $\mathrm{P}$ contents six times higher than $\mathrm{NG}$ ones (García et al., 2016). Our results agree with Beauregard et al. (2010), who also did not find response from AMF communities diversity to $\mathrm{P}$ fertilization treatments even with increases of available $\mathrm{P}$ from 84 to $693 \mathrm{mg} \mathrm{Kg}^{-1}$. Probably other factors together with initial and changes in $\mathrm{P}$ availability are affecting AMF diversity. One reason of the observed results could be related to a greater resilience of AMF community to nutrient changes than the vegetal community. As stated above, the agronomical practices caused changes in the floristic composition, promoting invasive species and reducing the presence of native ones (Jaurena et al., 2015). Given that there are around 270 AMF species (Castillo et al., 2016) that colonize approximately 200.000 plant species (Brundrett, 2009), mycorrhiza is an unspecific interaction, therefore invasive species that proliferated in fertilized plots (Lolium multiflorum and Cynodon dactylon) could maintain mycorrhizas with the same AMF species present in native grasses or could not be colonized by AMF. In both cases, there would be no replacement of AMF species. However, previous studies reported that invasive plants alter the AMF communities of native species and it has been proposed as a possible mechanism which contributes to the success of the invasion (Mummey et al., 2005). Further studies will be essential for determining if in- vasive plants are colonized with AMF and how this interaction is affected by $\mathrm{P}$ fertilization.

Moreover, the lack of response in AMF diversity to $\mathrm{P}$ increments could be due to the bias of T-RFLP technique used in the present study. Although this technique has the advantage of being really sensitive, it has been reported that this procedure could underestimate diversity because the same terminal fragment or T-RF could be representing more than one species that present the same restriction site in the sequence. To adjust the resolution of this technique more than one restriction enzyme could be employed, as well as the use of both marked primers (Dickie and FitzJohn, 2007).

Furthermore, we observed a trend in the number of spores in C. selloana rhizosphere which showed that $\mathrm{P}$ fertilization caused an increase on spore abundance in this grass. This result contradicts previous studies that reported long-term negative effects of $\mathrm{P}$ addition on spore density (Kahiluoto et al., 2001). Taking into account that $C$. selloana roots in fertilized plots had less mycorrhizas than in NG plots (García et al., 2016), the increase in spore abundance could be explained by a shift in resource allocation from the hyphas (functional structures that provide nutrients to plants) to dispersal and survival structures as spores. This change in allocation patterns could be caused by the increase in available $\mathrm{P}$ in soil, which operates as a selective force (Sheng et al., 2013). These authors suggest that in P deficiency conditions plants would allocate more carbohydrates to roots and root system would produce more exudates that promote hyphal growth. Increasing P soil levels triggers the investment of carbon and energy in propagules rather than in hyphal growth. As it was previously mentioned, C. selloana showed a decrease in its cover in fertilized grassland (decreaser species to P, Jaurena et al., 2015). Even though in this study we did not analyze plant performance, it is expected that $C$. selloana plants have less available carbon to allocate to their roots, what would lead fungi 
to produce more resistance structures (spores). On the other hand, Cumming et al. (2015) propose another explanation: a possible selection by the host plant or edaphic environment of the mycorrhizal fungus species that have the potential to increase $\mathrm{P}$ acquisition. In P. dilatatum (which its cover was indifferent to $\mathrm{P}$ increments according with Jaurena et al., 2015), although the mycorrhizal colonization was negatively affected due to $\mathrm{P}$ addition (García et al., 2016), AMF spore abundance in its rhizosphere did not change. These results could suggest that pattern of resources allocation was not modified in this grass species.

AMF communities showed differences between both grass species. AMF biotypes richness that colonized roots was greater in $C$. selloana than in $P$. dilatatum. These results agree with previous studies which found differences in fungal community composition (Mummey et al., 2005; Martínez-García et al., 2015) and in AMF biotypes richness between host plants (Algualcil et al., 2012). AM fungal richness may have positive effects on plants due to increased chances of functional compatibility. Moreover, spores abundance in the rhizosphere also showed differences between host plants. We found a significantly higher number of spores in the rhizosphere of C. selloana than in P. dilatatum in high $\mathrm{P}$ availability situations. It has been demostrated that there is a fungi-plant combination effect on the performance of the vegetal symbiont as well as on the fungal populations growth, which could present different sporulation rates (Boaming and Bever, 2016).

Although seasonal effect has been studied on AMF diversity in soil and rhizosphere (Dumbrell et al., 2011; Tian et al., 2011), this effect on AMF community diversity inside the roots has not been extensively studied. Different environmental conditions, as well as the phenology of host plants were found to cause changes in AMF colonization rates (Hazard et al., 2014). In a previous work, highest AMF colonization rates were found in summer (February), at peak growing times of P. dilatatum and C. selloana (García et al., 2016). In this study, the season of the year caused differences in the AMF community of $P$. dilatatum and C. selloana roots (Figure 2). Our results agree with previous studies in which seasonal variation in AMF communities have been suggested (Dumbrell et al., 2011; Hazard et al., 2014). We found higher AMF biotypes richness in P. dilatatum and C. selloana roots in winter than in summer (Figure 1). Similar results were found by Hazard et al. (2014) and Dumbrell et al. (2011). Bearing in mind that AMF depend on the carbon supplied by their host plant, these authors suggest that an increase in a limiting resource is expected to reduce both diversity and community evenness. This is due to the fact that stronger competitors are able to capture greater amounts of resources and so dominate. The decrease of diversity during the summer could be explained by this mechanism. The availability of carbon to the AM fungi is limited by low rates of photosynthesis during the winter. By contrast, in warm season an increase in carbon supply to the AM fungi results in an overall decrease in AM fungal diversity, explained by single taxa dominance. The exact mechanism for temporal variation in AMF has yet to be fully determined and further studies are needed which take into consideration the seasonal dynamics of AMF (Hazard et al., 2014).

Within the most abundant morphotypes in all the samples, spores that could apparently belong to the Glomus and Gigaspora genera were found. Predominance of the Glomus genus over the other genera in natural grasslands was previously reported (Alguacil et al., 2012). Glomus species present great adaptability and they have been reported associated to different plants and environmental conditions (Castillo et al., 2016). So that, we could expect that the most abundant AMF spores in all $\mathrm{P}$ treatments could be Glomus species. 
In recent years, increasing attention has been paid to the investigations of AMF diversity in natural grassland ecosystems (Mafaziya and Madawala, 2015). The present study is the first contribution to the knowledge of arbuscular mycorrhizal diversity in soil and plant using molecular techniques in Uruguayan grasslands. P. dilatatum and C. selloana presented AMF communities with great diversity showing Shannon indexes values between 1.8 and 2.7 Both grasses were colonized by a number of biotypes that ranged from 6 and 25 , which agrees with previous studies that employed the same methodologies (Mummey et al., 2005; Hazard et al., 2014). The high fungal diversity found in the studied grasses shows the importance that AMF could have in Uruguayan grasslands.

\section{Conclusions}

Our results showed that long-term $\mathrm{P}$ fertilization did not affect the diversity of arbuscular mycorrhizal communities neither in the rhizosphere nor in the roots of two of the most frequent grasses in Uruguayan grasslands. AM fungal community varied between the seasons (winter or summer), and slightly with the host plant. Differences in AMF richness between host species seem to indicate a certain degree of fungiplant specificity in this symbiosis.

Furthermore, the high presence and diversity of arbuscular mycorrhizas found in this study reflect the importance that these interactions may have in Uruguayan grasslands. The present study represents a new insight of the effects of $\mathrm{P}$ addition on natural grasslands.

\section{Acknowledgement}

The authors thank the Instituto Nacional de Investigaciones Agropecuarias (INIA), for the guarantee and logistic support to carry out this study. Graciela Quintans and the staff of the Experimental Station
Palo a Pique for letting us use the station infrastructure and coordinating cattle grazing. Felipe Lezama and Gerardo Parodi for field work collaboration; Alejandra Borges for the assessment on statistical analysis. This work was financed by the 1814 Project of the Clemente Estable Fund - ANII.

\section{References}

Alguacil, M., Díaz-Pereira, E., Caravaca, F., Fernández, D.A., Roldán, A. 2009. Increased diversity of arbuscular mycorrhizal fungi in a long-term field experiment via application of organic amendments to a semiarid degraded soil. Appl. Environ. Microb. 75, 4254-4263.

Alguacil, M., Torrecillas, E., Roldán, A., Díaz, G., Torres. 2012. Perennial plant species from semiarid gypsum soils support higher AMF diversity in roots than the annual Bromus rubens. Soil. Biol. Biochem. 49, 132-138.

Beauregard, M., Hamel, C., Nayyar, A., St-Arnaud, M. 2010. Long-term phosphorus fertilization impacts soil fungal and bacterial diversity but not AM fungal community in alfalfa. Microbial Ecol. 59, 379-89.

Bever, J., Schultz, P., Pringle, A., Morton, J. 2001. Arbuscular mycorrhizal fungi: more diverse than meets the eye, and the ecological tale of why. Bioscience. 51, 923-931.

Boaming, J., Bever, J. 2016. Plant preferential allocation and fungal reward decline with soil phosphorus : implications for mycorrhizal mutualism. Ecosphere. 7, 1-11.

Blaszkowski，J. 2003. http://www.zor.zut.edu.pl/ Glomeromycota/. Accessed: 16/08/2017, 15:00.

Brundrett, M. 2009. Mycorrhizal associations and other means of nutrition of vascular plants: understanding the global diversity of host plants by 
resolving conflicting information and developing reliable means of diagnosis. Plant Soil. 320, $37-77$.

Castillo, C., Borie, F., Oehl, F., Sieverding, E. 2016. Arbuscular mycorrhizal fungi biodiversity: prospecting in Southern-Central zone of Chile. A review. J. Soil Sci. Plant Nutr. 16, 400-422.

Chaudhary, V., O’Dell, T., Rillig, M., Johnson, N. 2014. Multiscale patterns of arbuscular mycorrhizal fungal abundance and diversity in semiarid shrublands. Fungal Ecol. 12, 32-43

Colombo, R., Fernández Bidondo, L., Silvani, V., Carbonetto, M., Rascovan, N., Bompadre, M., Pérgola, M., Cuenca, G., Godeas, A. 2014. Diversity of arbuscular mycorrhizal fungi in soil from the Pampa Ondulada, Argentina, assessed by pyrosequencing and morphological techniques. Can. J. Microbiol. 60, 819-827

Culman, S., Bukowski, R., Gauch, H., CadilloQuiroz, H., Buckley, D. 2009. T-REX: Software for the Processing and Analysis of T-RFLP data. BMC Bioinformatics. 10, 171.

Cumming, J.R., Zawaski, C., Desai, S., Collart, F.R. 2015. Phosphorus disequilibrium in the tripartite plantectomycorrhiza-plant growth promoting rhizobacterial association. J. Soil Sci. Plant Nutr. 15, 464-485.

Daniels, B., Skipper, H. 1982. Methods for the recovery and quantitative estimation of propagules from soil. In: N. Schenck. (ed). Methods and Principles of Mycorrhizal Research. American Phytopathological Society, St Paul, pp: 29-37.

Davison, J., Öpik, M., Zobel, M., Vasar, M., Metsis, M., Moora, M. 2012. Communities of arbuscular mycorrhizal fungi detected in forest soil are spatially heterogeneous but do not vary through- out the growing season. PLoS One. 7, 41938.

Di Rienzo, J., Casanoves, F., Balzarini, M., Gonzalez, L., Tablada, M., Robledo, C. 2014. InfoStat ver- sión 2014. Grupo InfoStat, FCA, Universidad Nacional de Córdoba, Argentina. URL: http://www. infostat.com.ar.

Dickie, I., FitzJohn, R. 2007. Using terminal restriction fragment length polymorphism (T-RFLP) to identify mycorrhizal fungi: a methods review. Mycorrhiza. 17, 259-270.

Dumbrell, A., Ashton, P., Aziz, Feng, G., Nelson, M., Dytham, C. 2011. Distinct seasonal assemblages of arbuscular mycorrhizal fungi revealed by massively parallel pyrosequencing. New Phytol. 190, 794-804.

García, S., Pezzani, F., Rodríguez, A., del Pino, A. 2016. Micorrizas en gramíneas nativas: efecto de la fertilización fosfatada a largo plazo. Agrociencia Uruguay. 20, 7-16.

Gollotte, A., van Tuinen, D., Atkinson, D. 2004. Diversity of arbuscular mycorrhizal fungi colonizing roots of the grass species Agrostis capillaris and Lolium perenne in a field experiment. Mycorrhiza. 14, 111-117.

Hammer, O., Harper, D., Ryan, P. 2001. PAST: Paleontological Statistics software package for education and data analysis. Palaeontol. Electron. 4, 9.

Hazard, C. Boots, B., Keith, A., Mitchell, D., Schmidt, O., Doohana, F., Bending, G.2014.Temporal variation outweighs effects of biosolids applications in shaping arbuscular mycorrhizal fungi communities on plants grown in pasture and arable soils. Appl. Soil Ecol. 82, 52-60

Jaurena, M., Lezama, F., Salvo, L., Cardozo, G., Ayala, W., Terra, J., Nabinger, C. 2015. The dilemma of improving native grasslands by overseeding legumes: production intensification or diversity conservation. Rangeland Ecol. Manage. 69, 35-42

Kahiluoto, H., Ketoja, E., Vestberg, M., Saarela, I. 2001. Promotion of AM utilization through reduced P fertilization 2. Field studies. Plant Soil. 231, 65-79. 
Liu, Y., Shi, G., Mao, L., Cheng, G., Jiang, S., Ma, X., An, L., Du, G., Collins, N., Feng, H. 2012. Direct and indirect influences of $8 \mathrm{yr}$ of nitrogen and phosphorus fertilization on Glomeromycota in an alpine meadow ecosystem. New Phytol. 194, 523-535.

Mafaziya, F., Madawala, S. 2015. Abundance, richness and root colonization of arbuscular mycorrhizal fungi in natural and semi-natural landuse types at upper hantana. Ceylon J. Sci. Biol. Sci. 44, 25-34.

Martínez-García, L., Richardson, S., Tylianakis, J., Peltzer, D., Dickie, I. 2015. Host identity is a dominant driver of mycorrhizal fungal community composition during ecosystem development. New Phytol. 205, 1565-1576.

Mummey, D., Rillig, M., Holben, W. 2005. Neighboring plant influences on arbuscular mycorrhizal fungal community composition as assessed by TRFLP analysis. Plant Soil. 271, 83-90.

Oehl, F., Laczko, E., Bogenrieder, A., Stahr, K., Bosch, R., van der Heijden, M., Sieverding, E. 2010. Soil type and land use intensity determine the composition of arbuscular mycorrhizal fungal communities. Soil Biol. Biochem. 42, 724-738.

Öpik, M., Moora, M., Liira, J., Zobel, M. 2006. Composition of root-colonizing arbuscular mycorrhizal fungal communities in different ecosystems around the globe. J. Ecol. 94, 778-790.
Pezzani, F., Montaña, C., Guevara, R. 2006. Associations between arbuscular mycorrhizal fungi and grasses in the successional context of a two-phase mosaic in the Chihuahuan Desert. Mycorrhiza. $16,285-295$.

Sheng, M., Lalande, R., Hamel, C., Ziadi, N. 2013. Effect of long-term tillage and mineral phosphorus fertilization on arbuscular mycorrhizal fungi in a humid continental zone of Eastern Canada. Plant Soil. 369, 599-613.

Smith, S., Read, D. 2008. Mycorrhizal Simbiosis. 3rd edition. Academic Press, New York, 787 p.

Tian, H., Drijber, R., Niu, X., Zhang, J., Li, X. 2011. Spatio-temporal dynamics of an indigenous arbuscular mycorrhizal fungal community in an intensively managed maize agroecosystem in North China. Appl. Soil Ecol. 47, 141-152

Trouvelot, S., Tuinen, D., Gianinazzi-pearson, M. 1999. Visualization of ribosomal DNA loci in spore interphasic nuclei of glomalean fungi by fluorescence in situ hybridization. Mycorrhiza. 8, 203-206.

Zhang, J., Wang, F., Che, R., Wang, P., Liu, H., Ji, B., Cui, X. 2016. Precipitation shapes communities of arbuscular mycorrhizal fungi in Tibetan alpine steppe. Sci. Rep. 6, 23488. 